\title{
THE MORPHOLOGY AND TYPOLOGY OF THE OTTOMAN MOSQUES OF NORTHERN GREECE
}

\author{
M. LOUKMA \& M. STEFANIDOU \\ Laboratory of Building Materials, School of Civil Engineering, Aristotle University of Thessaloniki, Greece
}

\begin{abstract}
The present study is an effort to categorize the Ottoman mosques in Greece at the region of Macedonia that have survived up until today. Categorization is the first step to study and understand each monument, in order to record its preservation state as well as to document the morphology and the typology of the existing mosques. The result of this study is to determine the appropriate way of intervention for the conservation and preservation of mosques. This study includes a total of 19 mosques. These monuments vary in the degree of preservation. Most of them have not acquired a new purpose, while some have been restored and used as cultural spaces in the course of time. The majority of mosques are severely damaged and have multiple interventions and serious alterations, mainly due to lack of preservation. Some of them have received extensive interventions and have been transformed into Christian churches. According to typology, the mosques are separated into two main categories: domed 'singleunit' mosques and 'multi-function' mosques.

Concerning the categorization data of the mosques of Macedonia many issues emerge, such as the lack of classification and the difficulty in dating them. As a result, today it is extremely difficult to separate the construction phases of the buildings and to determine their original form.
\end{abstract}

Keywords: conservation, domed mosques, morphology, Ottoman mosques, preservation, typology.

\section{INTRODUCTION}

The Ottoman Empire in the Balkans covers the period from the 14th century until the early 20th century [1]. The central province of the Ottoman Empire was the Greek region of Macedonia, where religious and cultural buildings were constructed with a wide variety of morphology and typology. During this period, cities along with their institutions were reformed and developed, such as Serres, Thessaloniki, Veria, Drama, Kavala and Kastoria, and new ones such as Giannitsa were found [2]. Despite the multicultural nature of the cities, each community had its own characteristics. The social and economic organization of the Islamic cities had a serious impact on their urban form. During this period the central financial institution named Vakuf controlled the operation of religious and cultural institutions of the city, whereby new public commercial and religious buildings were constructed.

Consequently, the image of the public space was influenced by the location of the central mosque and its dependent buildings as well as the covered market and inns. The importance of the mosque as a building in everyday life is clearly indicated by its location at the centre of the city and revolves around the fulfilment of religious duties and social ideals of Muslim citizens.

\section{PRESERVED MONUMENTS IN MACEDONIA REGION}

In Macedonia, only a few examples of monuments from the Ottoman era have been preserved (Fig. 1), and these monuments are an important part of its historical and cultural heritage.

This paper is part of the Proceedings of the International Conference on Islamic Heritage

Architecture and Art (Islamic Heritage Architecture 2016)

www.witconferences.com 


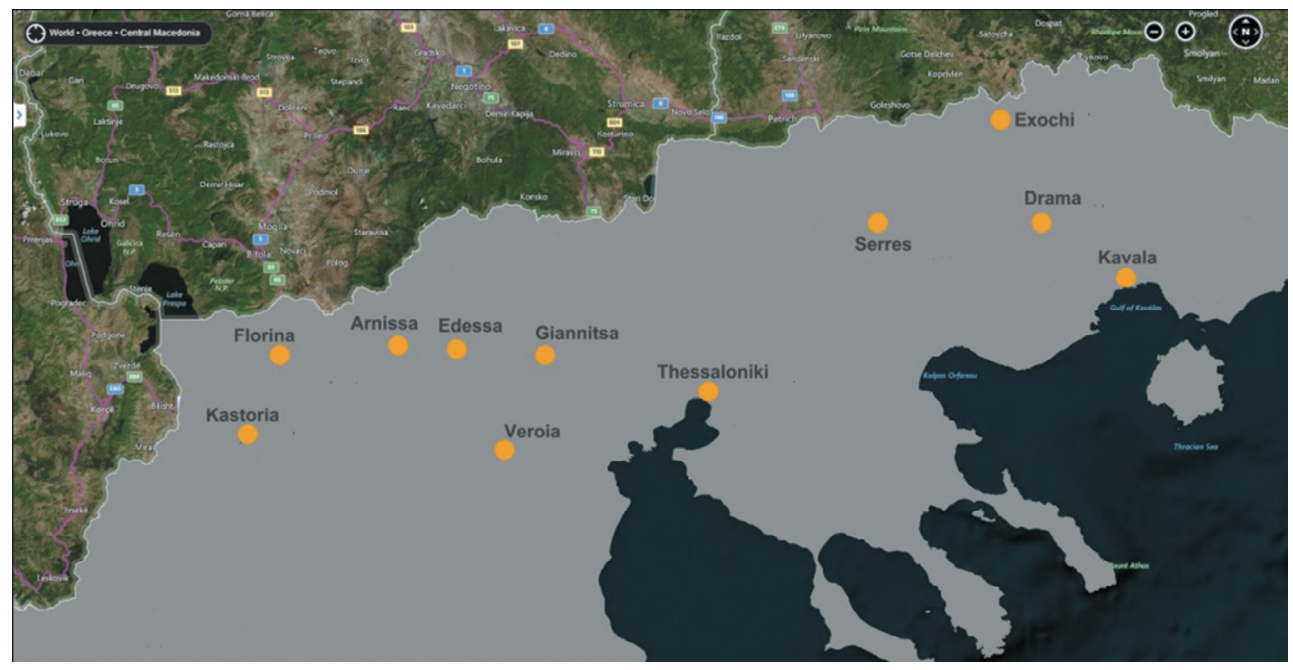

Figure 1: Map of Northern Greece with cities where Ottoman mosques exist.

During the present survey process, 19 buildings that were originally constructed as mosques were found. These are located in the cities of Serres, Thessaloniki, Veria, Edessa, Giannitsa, Drama, Kavala and Kastoria. Moreover, parts of four minarets indicating the existence of a mosque were recorded in the cities of Florina, Arnissa, Giannitsa and Veria.

The Ahmet Bey Mosque [3] in Giannitsa, Hamza Bey [4] and Ishak Pasha Mosque (or Alatza Imaret) [5] in Thessaloniki, Mehmet Bey [6] in Serres, Orta Mosque [7] in Veria and the Koursoumli Mosque [8] of Kastoria were dated in the 15th century. The Medresse Mosque [9] in Veria, Iskender Bey Mosque [10] in Giannitsa, Mustafa Bey [11] and Zintzirli [12] in Serres, the Eski Mosque (Church of St. Nicholas) [13] in Drama and the Ibrahim Pasha Mosque (Church of St. Nicholas) [14] were dated in the 16th century. The Arap Mosque [15], Sadirvan Mosque [15] and Koursoum Mosque (Agia Triada Church) [15] in Drama, the Geni Mosque [16] in Edessa and the Mosque of Halil Bey [17] in Kavala are dated in the 19th century. There are also a group of monuments which have not yet been dated, the Hounkiar Mosque in Edessa and the Mosque in the Exochi Drama [18].

Nowadays, it is extremely difficult to identify the construction phases of the monuments and determine their original morphology due to their preservation state.

\section{TYPOLOGY OF MOSQUES}

The typology of Ottoman mosques is based on the organization required by the rules of Islam, while the architecture is characterized by simplicity and geometry based on the tradition of each area.

The mosque can be characterized as a robust, cubic volume building with openings on its sides marked by the slender construction of the minaret rising on a corner. The orientation of the Ottoman mosque is set to south or south-east masonry - Qibla - where a niche is formed, the mihrab, indicating the direction of the Holy City to Muslims, Mecca, while the entrance to the prayer space is placed on the side opposite the Qibla wall and usually axially on this.

According to the typological characteristics, they are separated into two main categories: 'single-unit' mosques and 'multi-space' mosques. 
In the first category, as shown in Fig. 2, are the mosques that have a single prayer room almost in square ground plan with the presence of a portico in the facade.

The quadrangular plan view follows the contour of the central area. The plan is rectangular with a pillared portico on the front, which is intended primarily for those who do not enter the prayer room or for the overnumbered prayers. In mosques that survive with central quadrangular prayer space of various dimensions, differentiation on both the location and the access to the minaret and also to the form of the portico is observed. In most cases, the minaret has a rectangular base, located at the north-west corner of the prayer space as an extension of the bulk of the mosque, but can also have a multifaceted base plan (Ibrahim Pasha Mosque Agios Nikolaos Church - in Kavala and Medresse Mosque [19] in Veria) or not even attached to it (Halil Bey Mosque in Kavala).

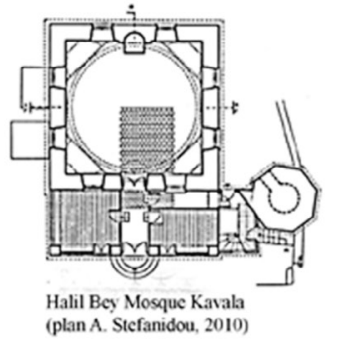
(plan M. Loukma, unpublished)

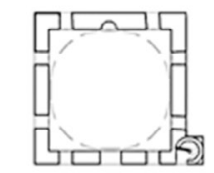

Koursoumli Mosque Kastoria

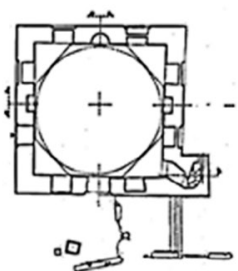

Orta Mosque Veria (plan B. Mavromatidou, 2003)

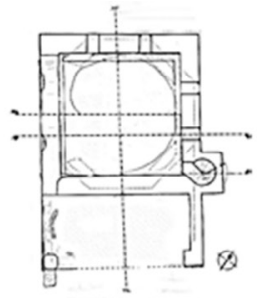

Ahmet Bey Mosque Giannits? (plan A. Chalkidi, 2010)

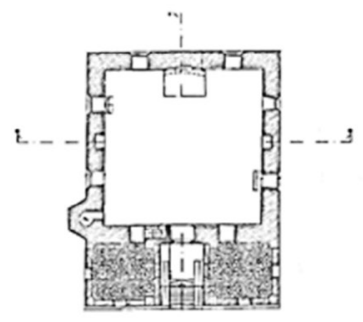

Medresse Mosque Veria (plan V. Kaltapanidou- F. Karagianni, 2010)

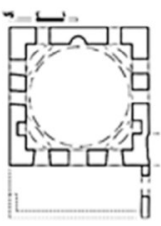

Exochi of Drama Mosque (plan M. Loukma, unpublished)

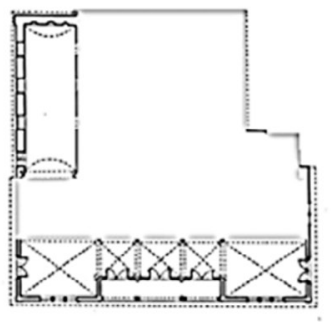

Ibrahim Pasa Mosque-Ag. Nikolaos Kavala (plan A. Stefanidou, 2010)

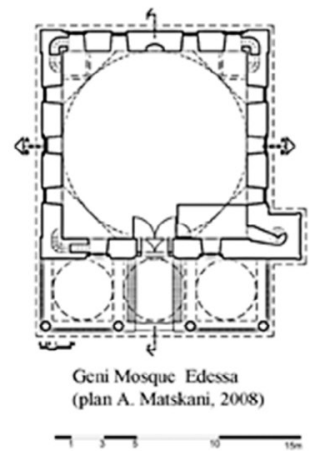

Figure 2: The ground plan of the first category mosques. 
The existence of the pillared portico extends into the north-west side of the mosque with an average length less than half of the tangential masonry walls, designating the movement of believers towards the entrance while at both sides at a higher level, there are two places to host the prayers. The porch is made of slightly pointed arches, or circular arcs, which through plume supports the roof. The arches of the portico are based on the main side walls and stone columns with a circular or polygonal base.

The main prayer space is lit by side openings arranged in rows and in many cases there were openings in the drum of the dome that formed the roof of the quadrilateral space. Two

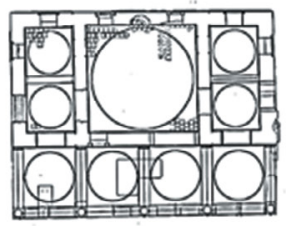

Mustafa Bey Mosque Serres (plan S. Dadaki, 2008)

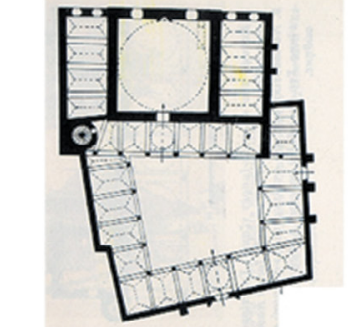

Hamza Bey Mosque Thessaloniki (http://www.ituom.gr/project/monuments/xamza.htm)

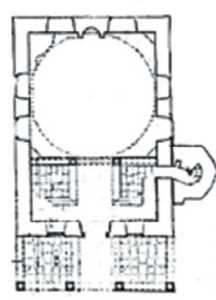

Arap Mosque Drama (plan A. Ageloudi, 2009) 2.

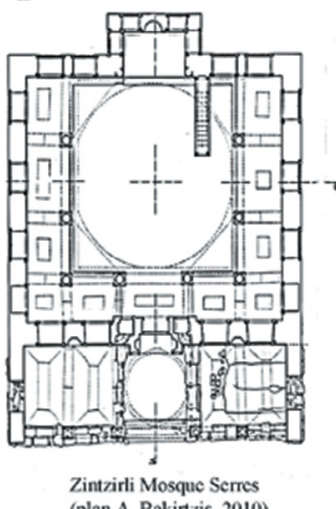

(plan A. Bakirtzis, 2010)

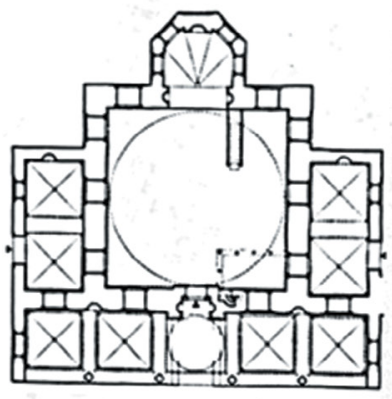

Mehmet Bey Mosque Serres (plan S. Dadaki, 2008)

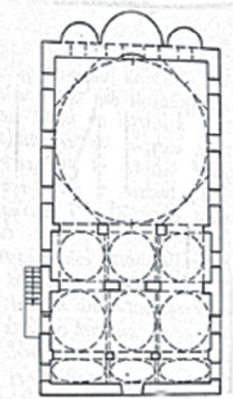

Eski Mosque - St. Nicholas Drama (archived by Ephorate of Antiquities of Drama)

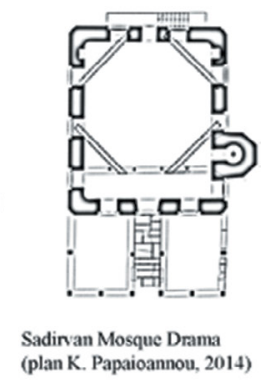

Sadirvan Mosque Drama (plan K. Papaioannou, 2014)

Iskender Bey mosque Giannitsa (plan M. Loukma, 2012)

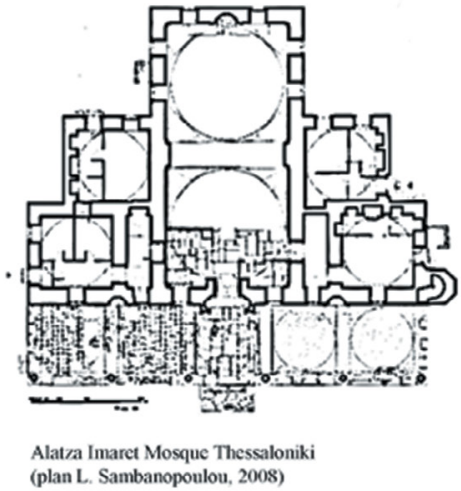

(plan L. Sambanoponlou, 2008)

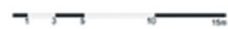

Figure 3: The ground plan of the second category mosques. 
openings in two zones are commonly observed, but also cases with one or three zones can be found.

The roof of the single prayer space is a hemispherical dome which commonly is based on drum (Halil Bey Mosque [20], Ahmet Bey Mosque [21], Geni Mosque [22] and Orta Mosque [23]) with openings and in some cases in corbel drum.

In the second category, as shown in Fig. 3, we have mosques with many spaces, which apart from the main quadrangular prayer room have smaller rooms serving social gatherings. Depending on how the spaces are organized the mosques can be further divided into two types according to their space arrangement or their roof types.

The first type includes rectangular plan mosques with spacious, open, quadrangle prayer area with internal various shapes, colonnade area and exterior portico. In Eski Mosque Church of St. Nicholas - the plan view is clearly elongated by three parallel porticos with colonnades having different width and roofing.

In this type, the mosque's roof is made of arches according to the size of each space, with an exception of Sadirvan Mosque [24] where the hipped tiled roof extends to the portico. Access to the minaret was either by an independent opening or by an arched opening at low height from the inside of the main mosque prayer space. The portico area in all mosques of this type follows the size of the main mosque prayer space. The main prayer space is illuminated by two opening zones. The first zone consists of rectangular openings while at the higher zone the openings have semicircular endpoints. The roof shape varies according to the space that has to be accommodated. In most cases, the roof at the central prayer space is a hemispherical dome and differentiates at the arcade and portico.

In the second type, attached in the perimeter, or in continuation of the main central prayer space, individual rooms are developed creating two different forms with pillared portico on the facade.

In one case, additional prayer halls were developed on either side of the central space in equal width creating a rectangular plan (Mustafa Bey Mosque in Serres, Hamza Bey Mosque [25] in Thessaloniki); this form was developed at least in two construction phases, based on the quadrangular central space. At the Hamza Bey Mosque, the original quadrangular central area formed the core to which rectangular buildings were added on either side and one open arcade on the west side, while the building complex was completed by the addition of threesided U-shaped asymmetrical portico plan, creating a wide quadrilateral patio.

In the second case, the final plan of the mosque was as an inverted T-shape, due to the reduced width of the side prayer halls and the predominance of the central space (Iskender Bey Mosque [26] in Giannitsa, Mehmet Bey Mosque in Serres, Alatza Imaret [27] in Thessaloniki). In all the cases, the main prayer space has an almost square plan, which in the case of the Alatza Imaret is doubled by a second equally sized space. In Iskender Bey Mosque, which is a partial sample of the total building complex due to extensive interventions received over the years, the longitudinal hall located in front of the main prayer space, having a characteristic arched opening, is not found in the other two mosques under investigation and there are no indications of their existence.

\section{MORPHOLOGICAL ELEMENTS}

The volume of every mosque is characterized by a geometric shape formed by a quadrangle or multifaceted with ribbed or semicircular openings on all sides and the roofing consists of hemispheric domes, both in the main prayer space and in the portico. The main prayer space is covered by a dome, supported by small quarto-spheres or by spherical triangles. 
The number of domes in the portico varies depending on the type of plan and the size of the monument. There are cases where instead of half-domes, ribbed cross-vault or their combinations are used.

\subsection{Construction materials}

The mosques under consideration fall under two categories regarding their construction materials. In the first category we have the mosques that were built from rows of stones and bricks, with a variety of types. In the second category, the mosques were built only with stones, while the domes are built entirely of mud bricks and mortar. The materials available in the region are inextricably linked with the construction techniques and played an important role in the architectural approach and the methods to be followed in order to construct the building. The building materials used were stones, mud bricks, mortar and wood, with which foundations, walls, arches and domes were made. Secondary materials such as marble, tiles or lead plates were used to bring the building into its final form.

The thickness of the masonry is made of rubble masonry we observed variations on the outer and inner surface. In all cases, the internal structure was not elaborated, so it was decorated either by painting or prismatic stalactites. Externally, in the first building category, the types of mosques vary in each monument by the number of bricks used around each stone, which can be single, double or triple. Hewn stones with two to three rows of bricks in zones used in Alatza Imaret of Thessaloniki and three facades of Zintzirli Mosque [28] in Serres (Fig. 4) are built in an accurate cloisonné according to the Byzantine Hellenic School. The hewn stone blocks are surrounded by a brick placed vertically at the side of each block.

Hewn or not, stone zones of three to four rows of bricks that form a building system of incomplete surrounding brick appears in Ahmet Bey Mosque in Giannitsa. Mustafa Bey Mosque in Serres and Koursoumli Mosque in Kastoria are built of rubble mixed with thin bricks in random manner, while the corners and the drums are built relatively more carefully with almost huge but hewn stones.

In Arap Mosque in Drama (Fig. 5) cornered stones were used at the edges of the sides. In Exochi of Drama Mosque (Fig. 5) semi-hewed stones were used, where there are three layers of bricks with rows on the lower level and two on the next with an intermediate mortar. The primer phase of Hamza Bey Mosque was built in a type of cloisonné with huge and hewn stones in the corners and the lower parts.

In the second category, the isodomic construction system, carved stones existing in Mehmet Bey Mosque in Serres (Fig. 6) where the exterior walls are faced with finely cut
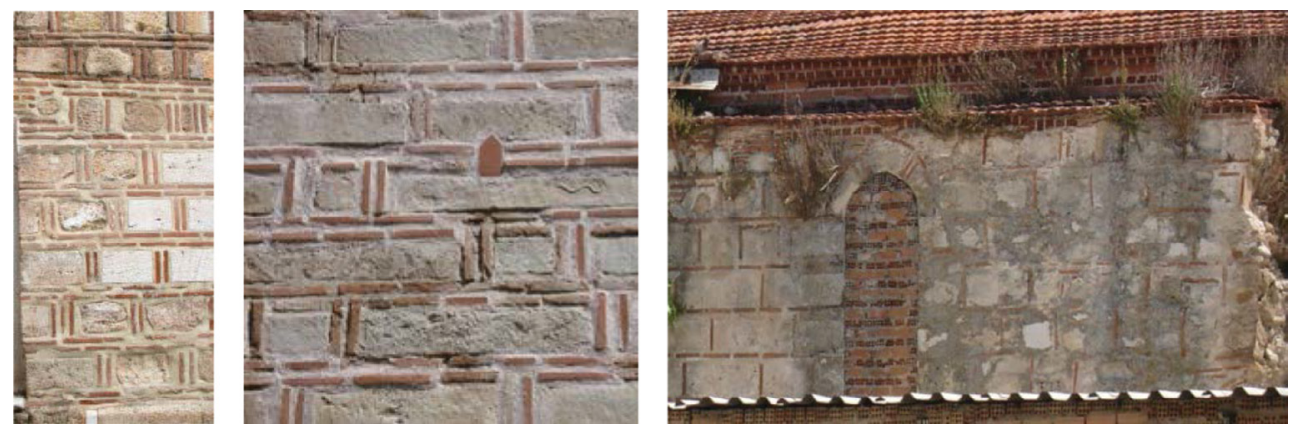

Figure 4: Masonry details from Alatza Imaret, Zintzirli Mosque and Iskender Bey Mosque. 

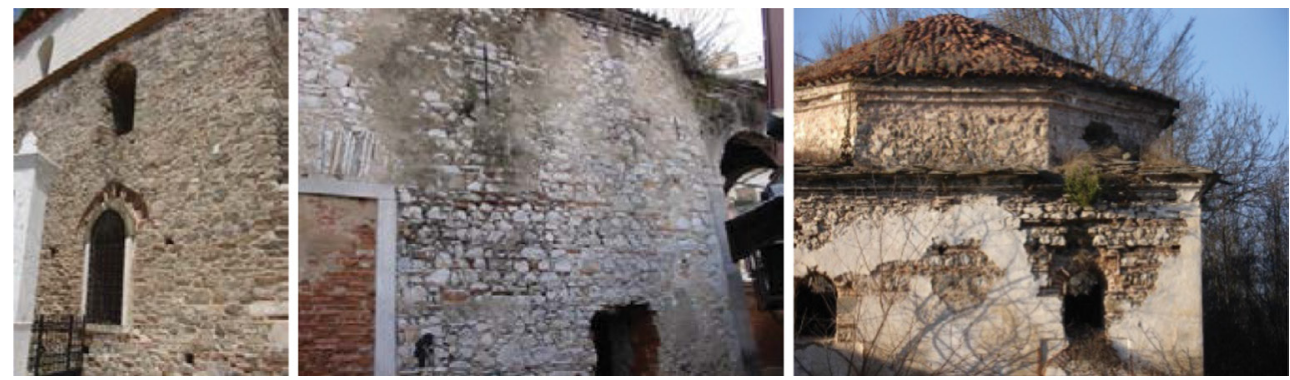

Figure 5: Masonry details from the Ibrahim Pasha Mosque, Arap Mosque and Exochi Mosque.
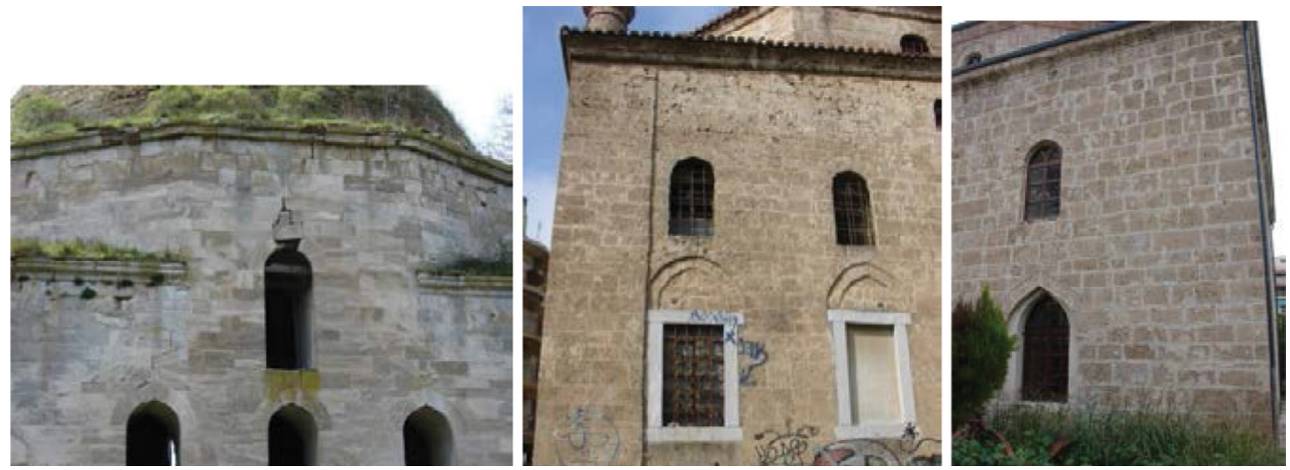

Figure 6: Masonry details from the Mehmet Bey Mosque, Geni Mosque and Medresse Mosque.
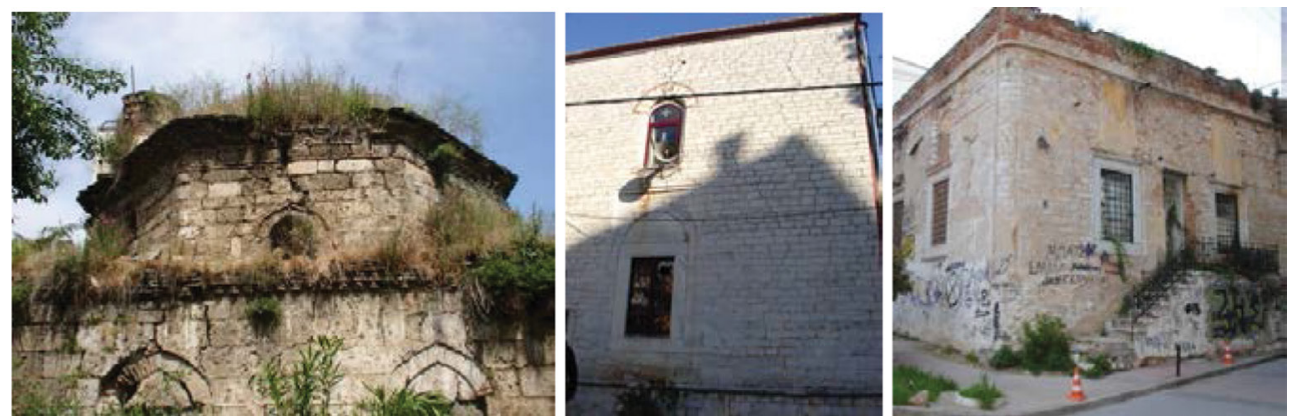

Figure 7: Masonry details from the Orta Mosque, Koursoum Mosque and Sadirvan Mosque.

yellow-ochre sandstone joined without the use of mortar on the surface, whilst mortar is used only to connect the core of the walls. Also, the same system using mortar binder was followed in the Geni Mosque in Edessa (Fig. 6), Medresse in Veria (Fig. 6) and Orta Mosque in Veria (Fig. 7), while in the Drama Koursoum Mosque (Church of Agia Triada) (Fig. 7) and the Sadirvan Mosque Drama (Fig. 7), boastful isodomic construction with small stones and mortar joints were used.

In all cases, the walls internally carry wooden piles along the sides, into zones by setting the height of openings. Externally, the walls and the drum of the dome bear culmination with cornice. 


\subsection{Opening configuration}

Light levels in a mosque are mostly related to the creation of an environment where prayer can fulfil a person's religious needs, rather than for regular visual comforts. The basic sources of illumination in the interior of the mosque are openings placed on walls and domes. Windows are arranged in all the views on different levels, from the base of the dome to ground level. The openings of the mosques are usually made by bricks. Openings with chiselled stones are shaped in Mehmet Bey Mosque, Zintzirli Mosque, Mentresse Mosque and Geni Mosque.

The first (bottom) zone usually has large rectangular openings with semicircular or ribbed arches. The arched outer endpoint is closed in most mosques; in Arap Mosque and in Sadirvan Mosque of Drama the bottom apertures are rectangles surrounded by marble without arched endpoint, while in some cases extra outer rectangular frame is created (Mehmet Bey Mosque, Eski Mosque-Church of St. Nicholas, Exochi mosque). The second and third zones are formed with smaller openings with circular or pointed arches. In two mosques (Mustafa Bey Mosque and Zintzirli Mosque) in the third zone there are circular skylights.

\subsection{Form of minaret}

The minaret is a key element of Ottoman architecture and is a characteristic part of the mosque. This is a tall structure adjacent to or embodied in the construction of every mosque. In the Ottoman mosques, the parts of minarets that survived are stone structures with circular interior staircase. In three cases, the main building has been demolished and only sections of the minaret have been salvaged. Minarets were mainly constructed with rectangular or polygonal base of stone masonry. The trunk was cylindrical in shape made of stone or bricks, ending in a decorated balcony. The staircase was spiral, made of stone steps, attached to the masonry and its vertical supportive column. In two cases the whole minaret was saved (Yeni Mosque Edessa and Medresse Mosque Veria), while in most cases, only the base and part of the trunk, with the interior stairway, were saved. There are several cases in which the minaret has been demolished but there are traces on the adjacent walls of the mosque (Mehmet Bey Serres, Mustafa Bey Serres, Zintzirli Drama Exochi and Eski Mosque - Church of Agios Nikolaos in Drama) where the base of the minaret was converted into a bell tower (Koursoum Mosque, Ibrahim Pasha Mosque in Kavala).

\section{CONCLUSIONS}

The surviving evidence of Ottoman architecture in Greece, in the region of Macedonia and especially in the Ottoman mosques that were studied, belongs to a period beginning from the second half of the 14th century until the end of the 19th century, with the exception of the 20th century.

Today, in the cities of Macedonia there are only a few Ottoman mosques, which are samples of Ottoman architecture and at the same time an important piece of historical and cultural heritage. The research showed that some of these monuments have been fully restored, some have been saved in a state of ruins or have been rebuilt, others have been repurposed, while a small number of them have been preserved or restored.

The goal of this study was to register the existing situation of mosques and gather information about their typological and morphological characteristics. This was achieved with clipping of published notices in conjunction with on-the-site investigation, photographic documentation and mainly digital drawings of the mosques where they did not exist. 
While recording the mosques of Macedonia, certain issues relating to the dating of the monuments emerged. More specifically three different cases were recorded: complete lack of dating of the mosques in the 17th and 18th centuries, insufficient (as it was based on individual items) or incomplete documents and inability of dating due to lack of information. A possible cause is the limited historical documents which were based on few studies and reports that have been carried on.

The grouping of the typological characteristics resulted in two main categories, based on their individual spaces that make up the mosques in today's state of preservation. The first category includes eight mosques that have a single prayer space with almost square floor plan. The second category with subcategories comprises 10 mosques. The morphological characteristics of the mosques of Macedonia listed are related to the construction materials, the morphology of openings and the shape of minarets as elements of a variety of styles that make up a remarkable unity of Ottoman architecture in Greece.

Finally, the understanding of the current situation of the mosques of Macedonia can clarify their components and their causes of deterioration. This will create the necessary knowledge for the treatment and rehabilitation of the damage and the simultaneous emergence of monuments. Furthermore, it will enable us to determine the appropriate mode of intervention so that the monuments will be part of the contemporary society receiving modern uses without prejudice to historical and aesthetic personality.

\section{REFERENCES}

[1] Kotzageorgi, F., The Ottoman Macedonia (end of 14th-end of 17th century), foundation museum of the Macedonian struggle (in Greek), http://www.imma.edu.gr/ history/06.html

[2] Zigomalas, D., The Protection of Architectural Monuments of Northern Greece from the Ottoman Conquest to the WWII (1361-1369), PhD thesis, Thessaloniki, p. 10, 2013. (in Greek)

[3] Skiadaresi, G., The Ottoman monuments of Giannitsa. FILIPPOS Quarterly Publication of Historical and Folkloric Society of Giannitsa, 76(3), p. 38, 2012. (in Greek)

[4] Sampanopoulou, L., Hamza Bey Mosque (or 'Alkazar'). Ottoman Architecture in Greece, ed. E. Mproyskari, Ministry of Culture, Directorate of Byzantine and PostByzantine Antiquities, p. 222, 2008. (in Greek)

[5] Sampanopoulou, L., Alatza Imaret (or Ishak Pasa Mosque), Ottoman Architecture in Greece, ed. E. Mproyskari, Ministry of Culture, Directorate of Byzantine and PostByzantine Antiquities, p. 229, 2008. (in Greek)

[6] Dadaki, S., Mehmet Bey Mosque (or Agia Sofia), Ottoman Architecture in Greece, ed. E. Mproyskari, Ministry of Culture, Directorate of Byzantine and Post-Byzantine Antiquities, p. 279, 2008. (in Greek)

[7] Tsilipakou, A., Orta Mosque, Ottoman Architecture in Greece, ed. E. Mproyskari, Ministry of Culture, Directorate of Byzantine and Post-Byzantine Antiquities, p. 297, 2008. (in Greek)

[8] Lowry, H., In the Footsteps of the Ottomans, Bahcesehir University Press: Istanbul, p. 208, 2009.

[9] Karagianni, F. \& Kaltapanidou-Pyrobetsi, V., Medresse Mosque, Ottoman architecture in Greece, ed. E. Mproyskari, Ministry of Culture, Directorate of Byzantine and PostByzantine Antiquities, p. 298, 2008. (in Greek) 
[10] Skiadaresi, G., Ottoman monuments of Giannitsa. Proceedings of the 3rd National Scientific Symposium, eds. A. Chrysostomou \& P. Chrysostomou, Edessa, p. 113, 2014. (in Greek)

[11] Dadaki, P., Mustafa Bey Mosque, Ottoman Architecture in Greece, ed. E. Mproyskari, Ministry of Culture-Directorate of Byzantine and Post-Byzantine Antiquities, p. 282, 2008. (in Greek)

[12] Mpakirtzis, A. \& Sampanopoulou, L., Zintzirli Mosque, Ottoman Architecture in Greece, ed. E. Mproyskari, Ministry of Culture, Directorate of Byzantine and PostByzantine Antiquities, p. 284, 2008. (in Greek)

[13] Lowry, H.W., An unknown fourteenth century Sultanic Mosque in the Macedonian city of Drama: the Yildirim Bayezid Cami. Monuments, Patrons, Contexts: Papers on Ottoman Europe presented to Machiel Kiel, eds. M. Hartmuth \& A. Dilsik, Nederlands Instituut Voon Het NabijeOosten: Leiden, pp. 15-28, 2010.

[14] Stefanidou, A., Ibrahim Pasa Mosque, Ottoman Architecture in Greece, ed. E. Mproyskari, Ministry of Culture, Directorate of Byzantine and Post-Byzantine Antiquities, p. 264, 2008. (in Greek)

[15] Messis, V., Drama through the remaining religious buildings of the Ottoman period. An example of Inatake and exposure of the local history through the teaching practice. Scientific Educational Magazine 'ekp@ideytikos', 3(1), pp. 188-190, 2015. (in Greek)

[16] Karagianni, F., Geni Mosque, Ottoman Architecture in Greece, ed. E. Mproyskari, Ministry of Culture, Directorate of Byzantine and Post-Byzantine Antiquities, p. 304, 2008. (in Greek)

[17] Mpakirtzis, A., Halil Bey Mosque and Medreses, Ottoman Architecture in Greece, ed. E. Mproyskari, Ministry of Culture, Directorate of Byzantine and Post-Byzantine Antiquities, p. 265, 2008. (in Greek)

[18] Messis, V., Ottoman mosque in the Exochi of Drama and the mosque of Karatza Pasha in GkotseNteltsef Bulgaria. Diode, Bi-annual Periodical Publication Speech art Drama, 8(1), pp. 68-91, 2015. (in Greek)

[19] Kaltapanidou, V. \& Karagianni, F., The Medresse Mosque of Veria: archeological excavations and restoration work. Monument and Environment, 11, p. 2, 2010. (in Greek)

[20] Mpakirtzis, A., Halil Bey Mosque, Ottoman Architecture in Greece, ed. E. Mproyskari, Ministry of Culture, Directorate of Byzantine and Post-Byzantine Antiquities, p. 266, 2008. (in Greek)

[21] Argirakis, D., Xalkidi, A., Skiadaresis, G., Ignatakis, Ch., Karadedos, G. \& Stefanidou, A., The mosque of Ahmed Bey in Giannitsa: restoration study and structural aid. The Archaeological Project in Macedonia and in Thrace, 23, 2009, Ministry of Culture \& Aristotle University of Thessaloniki, pp. 183-194, 2013. (in Greek)

[22] Matskani, A., Study of Maintenance-Restoration-Reuse of the Geni Mosque in Edessa, MSc thesis, 2008. (in Greek)

[23] Mavromatidou, B., Restoration of Orta Mosque in Veria, MSc thesis, 2003. (in Greek)

[24] Papaioannou, K. \& Papaioannou, H., Analysis-Documentation and Proposal for Restoration of the Former Sadirvan Camii Mosque at Armen Street of Drama, RAYCAP A.E., 2014. (in Greek)

[25] Raptis, K., Omirou, Th. \& Xanthos, V., Comments on the architecture of Hamza Bey Mosque (Alcazar) in response to the recent work of the monument protection. The Archaeological Project in Macedonia and in Thrace, 21, 2007, Ministry of Culture \& Aristotle University of Thessaloniki, pp. 241-246, 2010. (in Greek) 
[26] Loukma, M., The Iskender Bey Mosque in Giannitsa: Documentation and Restoration Study, MSc thesis, 2011. (in Greek)

[27] Kornaraki, K. \& Spiliopoulos, A., The Alatza Imaret. Historical report and description of the monument. The Preservation and the Restoration of Ottoman Monuments in Greece, ed. A. Stefanidou, EMMABP AIMOS, University Studio Press: Thessaloniki, pp. 89-103, 2009. (in Greek)

[28] Ameen Fatouh, A., Byzantine Influences on Early Ottoman Architecture of Greece, $\mathrm{PhD}$ thesis, Athens, p. 111, 2010. 